\title{
STRATEGIES FOR PROFESSIONAL DEVELOPMENT OF STAFF IN ECONOMIC ENTITIES IN THE FIELD OF ICT
}

\author{
Lilia Sava ${ }^{1 *}$, ORCID ID: 0000-0002-4318-9486, \\ Pavel Nistiriuc ${ }^{1}$, ORCID ID: 0000-0001-5189-7987, \\ Lucia Gujuman ${ }^{1}$, ORCID ID: 0000-0001-7940-4291, \\ Valentina Tîrșu², ORCID ID: 0000-0002-1726-792X, \\ Serafima Sorochin ${ }^{1}$, ORCID ID: 0000-0002-8334-6853 \\ ${ }^{1}$ Technical University of Moldova, 168, str. Ștefan cel Mare, Chișinău, Republic of Moldova \\ ${ }^{2}$ Moldova State University, 60, str. Alexei Mateevici, Chisinau, Republic of Moldova \\ ${ }^{*}$ Corresponding author: Lilia Sava, Lilia.sava@tse.utm.md
}

\begin{abstract}
The rapid pace of change in society has significantly influenced the evolution of economic entities in the field of ICT, which has led them to change their development strategy. The article analyzes the implementation of modern technologies in the production process, the service delivery process, as well as the implementation of progressive management methods in the fields of activity of economic entities. Staff development becomes a necessary premise to be able to react quickly and as flexibly as possible to change, this being possible only through a close correlation of the professional development strategy and the organizational strategy in the economic entities in the field of ICT.
\end{abstract}

Keywords: management, professional development, creative development, strategies, skills.

Rezumat. Ritmul rapid al schimbării din societate a influențat considerabil evoluția entităților economice din domeniul TIC, ceea ce le-a determinat să își schimbe strategia de dezvoltare. Articolul analizează implementarea tehnologiilor moderne în procesul de producție și în procesul de prestare a serviciilor, precum și implementarea unor metode progresive de administrare în domeniile de activitate ale entităților economice. Dezvoltarea personalului devine o premisă necesară pentru a putea reacționa rapid și cât mai flexibil posibil la schimbări, acest lucru fiind posibil doar printr-o strânsă corelare a strategiei de dezvoltare profesională și a strategiei organizaționale în entitățile economice din domeniul TIC.

Cuvinte cheie: management, dezvoltare profesională, dezvoltare creativă, strategii, competențe.

\section{Introduction}

Economic entities in order to become competitive must invest not only in quality products and services, but also in people, ie in that element that can make those products and services competitive. It is relevant for the managers of economic entities to be aware of 
this fact and to consider the professional development activity as a strategic activity for the organization.

Professional development includes the entire staff of economic entities, but refers more to the management staff of economic entities (managers at all hierarchical levels), as well as some specialists with technical skills.

The professional development of the staff aims to increase and diversify the professional skills of employees in order to involve them in more complex activities and with a much greater responsibility. Also, staff development involves changing the attitude regarding the involvement of employees in various activities within the organization and applying the best reasoning in order to make innovative decisions. Personnel development also involves the formation of responsibility for the activity carried out, as a personal quality of each employee.

The human resources development activity must be performance-oriented, being designed to ensure the specified level of growth of the performance of economic, functional, team and individual entities, making a significant contribution to the profitability of the organization. Human resources development plans and programs must be integrated into all economic and human resource strategies that they must support.

\section{Staff development strategies}

Personnel development must be seen as a strategic activity, which takes into account the development objectives of the economic entity.

The long-term development strategy of the economic entity in order to be successful will have to include the human resources strategy which, the only source of added value over time, which will aim at the professional development of human resources as a separate strategy. Thus, the human resources development strategy will have to take into account both the possibilities of the employer and the employee [2].

Based on the above, the author proposes a model of staff development strategy through the prism of the economic entity and the employer as a component part of the human resources strategy.

Based on the proposed model, it can be mentioned that staff development through the prism of the economic entity implies its ability to be aware of the important role of each employee and the need to develop its potential.

Professional development through the prism of the employee is based on the awareness of each employee to be continuously trained through lifelong learning, to meet the new requirements, increasingly larger and more challenging.

Considering the complexity of this strategy, the senior management of the economic entity must first identify the possibilities of the economic entity to ensure the professional development of employees and, at the same time, assess the intellectual potential of each employee and the professional development needs of employees.

\section{Staff development through the prism of the employee}

From the point of view of the economic entity, staff development is a much more complex activity, requires the consideration of several aspects and requires the implementation of several actions that have a higher or lower tangent.

In order to identify areas where professional development is required, it is first necessary to carry out an assessment of employees' professional skills. 


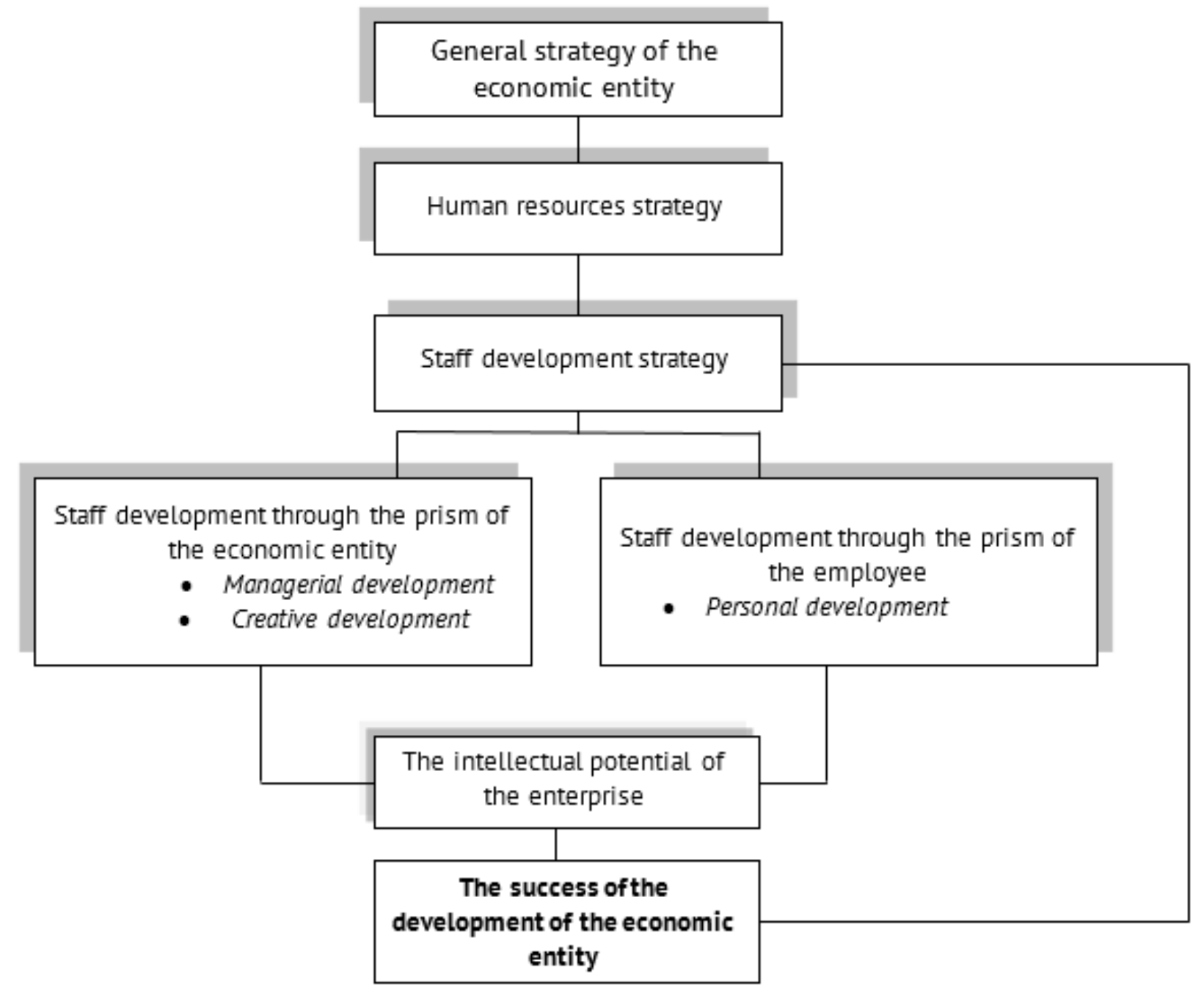

Figure 1. Employee development strategy from the point of view of the economic entity and the employee.

However, the evaluation of performances serves as a basis for making decisions on professional development for certain categories of staff or for employees of one or another subdivision of the organization.

Second, the economic entity must know the development potential, at least for certain categories of employees. For this it is necessary to evaluate the capacities of the employees and to identify the possibilities of their development. In this case, the economic entity needs to know what the maximum level of professional development is, especially for "key" employees.

Third, the economic entity must identify the individual objectives of employee professional development. In this case, the personal development objectives of the employees must coincide with the development objectives of the economic entity. The main objectives of professional development of the employee are: professional promotion, recognition, improvement of one's own image, taking on greater responsibilities, etc. The achievement of these objectives by the employee are also attractive for the organization because the employees with outstanding performances are attached and interested in its development. 


\section{Managerial development}

Managerial development refers to improving the performance of managers in their current positions and preparing them for strategic decisions in the future.

According to the "Statement of Principles on Managerial Development", "the managerial statement is any effort to improve managerial effectiveness through a planned and deliberate learning process" [8].

In the opinion of the scientist Mumford, in order for the managerial development system to be efficient, it is necessary to combine three elements:

- self-development is based on the idea that the individual can learn and that the initiative for development must belong to him;

- development initiatives at the level of the economic entity - the formal systems and programs for the development of managers must be developed by the specialists of the human resources department;

- development initiatives taken by superiors - the actions undertaken by senior managers regarding the development of managers at lower levels focused on real work issues.

The economic entity must conceive a philosophy of managerial development that ensures the performance of constant activities, meant to improve the way management is learned. For the economic entity in the field of ICT, the study of management can be done as a result of formal training, through courses organized within economic entities or outside it.

For managers under the age of 40 we consider it appropriate to use different modalities of managerial development, taking into account the fact that they already have a certain level of managerial training obtained in higher education institutions, both in the Republic of Moldova and beyond its borders. In this sense, for young managers, managerial development can be achieved by rotating positions, participating in teams or project groups, detachment outside the organization, which would allow them greater opportunities to accumulate managerial experience.

Lately, there is more and more talk about managerial development focused on skills requirements that must include the following fundamental elements:

- strategic capacity. This involves: a good understanding of the changing economic environment, an understanding of product and market development opportunities, and the acquisition of the strengths and weaknesses of one's own organization;

- capacity to manage change. It considers the identification of the need for change, the design of change programs, attracting the participation of other employees in the implementation of changes, etc.;

- ability to work in a team. It involves facilitating the collaboration in good conditions of people with specialized and different skills.

\section{Creative development}

An essential element for the existence and progress of society in general and of economic entities in particular is the creative theoretical and practical development of human resources, as a superior form of manifestation of their potential. The recent changes in local organizations, characterized by: accelerating the process of change, increasing the role and value of information, diversifying the tools and techniques used by managers, etc., have 
determined the need for a creative development of staff, especially managers at all hierarchical levels.

The need to create can be determined by the existence of a dysfunction (there is a real problem), but also by the desire to progress, without real dysfunctions, to strengthen the position in relation to competing organizations, in a spirit of competition, etc.

Considering the importance and complexity of creativity in organizations, it is necessary to focus from the beginning on those aspects that could have a favorable impact on the further development of creativity [1]. The analysis of the theoretical research highlights that the premises of creativity at the level of the organization can be:

1. The training of staff for creative development depends, first of all, on the quality of the human resources selection. By selecting a person who meets the requirements of the job and in terms of creativity, the chances of achieving organizational goals increase considerably.

2. Socio-economic premises. The need for creativity is often the result of the forces acting for change, namely: technical progress, competitive pressure, accelerated moral wear and tear of products; major changes in the workforce, etc.

3. Organizational premises. Any activity must be coordinated to achieve its goal. Or, creative development is an activity that involves a greater involvement of more people.

Starting from the stated premises, in order to stimulate the creative development, the activity of senior management must be oriented towards:

- creating a good climate of communication both internal (own staff, marketing department, research and development department) and external (inventors, research institutions, creativity centers), taking into account the principle that "all people have the creative potential";

- identification, recruitment and selection of persons to meet the requirements related to creativity;

- ensuring the permanent training and improvement of the staff (one step before the technical progress);

- ensuring conditions for a better development of group work, through an adequate management (for example, contributory management);

- creating an organizational framework conducive to creativity (for example, the idea box), as well as temporary or permanent creativity teams, such as quality circles;

- the belief that the most appropriate methods of stimulating creativity are used.

The result of the diagnosis of the professional development activity of the staff in the ICT field, allows us to generalize a SWOT analysis, which offers us a deeper understanding of both the strengths and weaknesses, as well as the opportunities and threats [9].

As a result of combining these four elements of the SWOT matrix, we can make several decisions regarding the professional development of the staff. The most conclusive can be considered the combination of strengths with opportunities and threats and that of weaknesses with opportunities. And the most risky and unwanted would be the combination of weaknesses with threats.

We can conclude that all decision-making options must focus on the elaboration and implementation of strategies and policies whose materialization will lead to the improvement of the professional development management of the staff. 
Table 1

\section{SWOT Matrix}

\section{Strengths}

1. Ensuring the knowledge and professional skills that the economic entity needs to carry out the activity;

2. Increasing the value of human capital of the economic entity;

3. Ensuring high professional competencies for all employees in order to perform the tasks and responsibilities related to the jobs they hold;

4. Employees' participation in the process of elaborating personal and managerial development plans;

5. Achieving organizational objectives, both short-term and long-term, with the help of highly qualified employees.

\section{Weaknesses}

1. Lack of staff training and development policies and strategies;

2. Lack of managerial development objectives for employees holding management positions;

3. Insufficient allocation of financial resources for training and professional development of staff;

4. Lack of initiative on the part of employees to participate in professional development;

5. Lack of technical-material base, centers for continuous development within economic entities for training and professional development of staff economic entities.

\section{Opportunities}

Threats

1. Changing the mentality of senior managers, in the sense that human resources must become an element of investment for the further development of the economic entity;

2. Awareness of the senior managers of the economic entity, establishing the objectives of implementing the professional development strategies of the specialized personnel;

3. Awareness by staff of the need for continuous training and personal development.

\section{Conclusions}

The professional development of employees has become necessary with the continuous development of new technologies and their implementation in economic activity.

If in the past people who acquired a profession or trade managed, based on the knowledge gained during school, to practise it throughout their lives, today knowledge expires very quickly, which leads to non-performance rather than performance by those employees.

The existence of some employees who no longer manage to keep up, professionally, with the changes that take place in the way of carrying out the activities in the competitive economy is a problem that worries more and more organizations. In the organizations of the Republic of Moldova, the activity of training and professional development is perceived as a necessity, but it is not yet a priority. In the current period of rapid change that ICT 
organizations in the Republic of Moldova are going through, training and professional development must become a continuous and organized process that takes into account all the changes that take place in organizations, as well as possible external challenges that could affect the subsequent work of organizations.

Taking into account the above, we can formulate the following recommendations.

1. The need to implement the staff development strategy in the general strategy of the economic entity. The strategy will detail all the actions that must be taken so that economic entities do not suffer from the lack of knowledge and professional skills in order to achieve the proposed objectives.

2. Inclusion of the staff development strategy in the human resources strategy, in particular, and in the strategy of economic entities in general. This means that staff development becomes a necessary premise in order to be able to react quickly and as flexibly as possible to changes in the truly competitive environment.

The close correlation of the professional development strategy and the organizational strategy in the economic entities in the field of ICT, will amplify the need of the economic entities for an overview or an integrated approach to the respective issue, in which more and more must be taken into account the fact that human potential cannot always be adapted only in the short term. Achieving this goal requires a change of attitude or a change of behavior on the part of senior managers.

3. Awareness of senior managers and managers of functional subdivisions of economic entities in order to address the issues of professional development of staff by including in the job description the tasks and obligations in question. This will increase the responsibility of these specialists.

Acknowledgments. This paper work was presented at the "International Conference on Electronics Communications and Computing, IC ECCO”, 21-22 October, 2021, Chisinau, TUM.

\section{References}

1. Androniceanu A. Managementul schimbărilor: valorificarea potenţialului creativ al resurselor umane. Editura ALL Educational, Bucureşti, 1998.

2. Armstrong M. Managementul resurselor umane. Manual de practică, Editura CODECS, Bucureşti, 2003.

3. Bîrcă A. Managementul resurselor umane, Manual, Editura ASEM, Chişinău, 2005.

4. Munteanu I., Ioniţă V., Managementul cunoştinţelor, Editura Cartier, Chişinău, 2005.

5. Panișoara G., Panișoara I.O. Managementul resurselor umane. Bucureşti: Polirom, 2017.

6. Petrescu I. Managementul personalului organizaţiei, Editura Expert, Bucureşti, 2003.

7. Rotaru A., Prodan A., Managementul resurselor umane, Editura Sedcom Libris, Iaşi, 1998.

8. Rameshbabu H. Critical Approaches to Management Development: A Study. International Jurnal of Research in Business Study, Volume 4, 2017.

9. Bekesi D. Evaluation of professional. Performance of employees in the public sector. [accesat 10.10.2021]. Disponibil:https://www.coursehero.com/file/66665082/EVALUATION-OF-PROFESSIONAL-PERFORMANCEOF-EMPLOYEES-IN-THEpdf/

10. Importanţa formării profesionale şi rolul acesteia [accesat 10.10.2021]

Disponibil:http://competitiv.bethany.ro/? 342 p. 